\title{
Статево-вікові особливості ідентичності: крос-культурний аспект
}

\author{
О. Г. Шмиглюк
}

Кафедра психології розвитку та консультування, Житомирський державний університет імені Івана Франка

Corresponding author. E-mail: @shmyglyuk.oksana@gmail.com

Paper received 10.09.18; Accepted for publication 15.09.18.

https://doi.org/10.31174/SEND-PP2018-175VI73-14

Анотація. Статтю присвячено вивченню особистісної та соціальної ідентичності представників польської та української етнічних груп. На основі теоретичного аналізу встановлено, що ідентичність - це той фундамент, який визначає світогляд людини, впливає на формування картини світу та Я-образу особистості, усвідомлення та розуміння себе та оточуючих, що визначає здорову, гармонійну поведінку особистості в суспільстві. Здійснено емпіричне дослідження етнічних та статево-вікових особливостей ідентичності українців та поляк. 3'ясовано, що існують етнічні та статево-вікові відмінності у ієрархічній структурі ідентичності. Констатовано, що у сучасних поляків простежується переважання конструкту цінностей та моральних переконань, а для української вибірки найбільше значення має самооцінка.

Ключові слова: ідентичність, особистісна ідентичність, сочіальна ідентичність, украӥнці, поляки, етнос, етнічна самосвідоMicmb.

Вступ. Науковий інтерес до вивчення ідентичності стає все більш помітним та є закономірним, як реакція науковців на культурно-політичні події, що відбуваються в Україні й в багатьох країнах світу. Соціальні, політичні, культурні, демографічні зміни безпосередньо та опосередковано впливають на процес становлення, розвитку та трансформації особистості, на розуміння людиною себе та інших, усвідомлення своєї позиції у соціумі.

Формування самосвідомості, самовизначення, ідентичності є важливою передумовою становлення гармонійної та здорової особистості і як наслідок здорового суспільства. Наразі реалії українського суспільства (економічна та соціальної нестабільності, затяжні військові дії) такі, що сприяють виїзду українців за кордон. Значна кількість людей мігрують до Польщі, як до братньої країни 3 подібним менталітетом та родинними зв'язками, а також зі схожою міграційною ситуацією. У зв'язку з тим, що ідентичність це - закономірне якісне змінення уявлень про своє місце в соціальному світі протягом життя під впливом різних факторів» [5], постає нагальна потреба у дослідженні ідентичності сучасного українця та поляка.

Короткий огляд публікацій по темі. Проблема ідентичності є широко дослідженою у психологічній науці. Інтерес до даного феномену з'явився досить давно, ще 3 початком розвитку та формування психологічної науки та простежувався у філософських концепціях.

Єдиного підходу до визначення даного поняття не існує. Науковці розуміють ідентичність як складне, багаторівневе особистісне утворення; внутрішню неперервність та тотожність особистості; здатність людини зв'язано, цілісно сприймати свою поведінку та життя; як власну особистість пов'язану із процесом самосприйняття та внутрішньою перспективою індивіда; як почуття самототожності, власної істинності, повноцінності, причетності до світу та до інших людей; почуття набуття, адекватності та стабільного бачення себе, володіння особистістю власним «Я», незалежно від зміни оточуючої ситуації; це здатність особистості до повноцінного вирішення завдань, які постають перед нею на кожному етапі розвитку; цілісність особистості, як ії інтегративна властивість; ступінь відповідності людини групі, статі, етносу, роду та іншим категоріям; самість, істинність індивіда [7, 10, 11, 2, 1, 9]. Ідентичність - (від англ. identity - тотожність) - це бага- тозначний життєвий та загальнонауковий термін, що виражає ідею постійності, тотожності, спадкоємності індивіда та його самосвідомості [6].

Так феноменологічні та структурні особливості ідентичності розглядалися 3. Фройдом, Дж.Мідом І. Гоффманом, Х. Тейфелом, Дж. Тернером, М. Хогом, В.С. Агеєвим, В.А. Ядовим, Ю.Хабермасом, Б.Войчишке (Wojciszke) та М.Яримович (Jarymowicz) . Вікові особливості та розвиток ідентичності вивчали Дж.Марсіа, Е.Еріксоном, як ціннісно-смисловий компонент ідентичність розглядається у працях А. Ватермана.

Перше детальне розкриття поняття ідентичності належить Е. Еріксону, на думку якого, ідентичність - це складне, багаторівневе особистісне утворення[10]; внутрішня неперервність та тотожність особистості[11]. При цьому iii рівні обумовлені рівнями аналізу природи людини: індивідний (ідентичність розуміється як усвідомлення людиною власної певної незмінної даності, своєї фізичної зовнішності, темпераменту, задатків тощо - тобто як протяжність у часі), особистісний (ідентичність розглядається як відчуття людиною власної неповторності, унікальності свого життєвого досвіду, що задає певну тотожність самому собі), соціальний (ідентичність як певний особистісний конструкт, за допомогою якого ми відрізняємо схожих та несхожих на себе, який відображає внутрішнє прийняття людиною соціальних ідеалів та норм.)[10]. Ідентичність, як здатність людини зв'язано, цілісно сприймати свою поведінку та життя розглядав Дж. Мід, виділяючи усвідомлену (здатність людини за допомогою набутої в соціальній взаємодії мові розмірковувати про себе, усвідомлювати свою ідентичність) та неусвідомлену (несвідоме прийняття певних норм, очікувань тієї соціальної групи, до якої належить людина.) ідентичність[2]. Продовжив ідеї Дж.Міда I. Гоффман, який запропонував виділяти три види ідентичності: соціальну ідентичність (наділення особистості іншими людьми соціальними атрибутами групи, до якої вона належить); особистісну ідентичність (включає в себе індивідуальні ознаки людини (наприклад, усі унікальні ознаки, унікальні комбінації фактів та дат історії людини); Я-ідентичність (передбачає суб'єктивне відчуття індивідом свого життя, своєї безперервності та унікальності) [7]. Цікавими є дослідження Ю.Хабермаса, який стверджує, що Яідентичність реалізується на перетині особистісної та со- 
ціальної ідентичності. Особистісна ідентичність забезпечує єдність історії життя індивіда, а соціальна - можливість виконувати вимоги соціальних систем. Науковець звертає увагу на те, що «встановлення та підтримка балансу між особистісною та соціальною ідентичністю здійснюється за допомогою технік взаємодії, серед яких важливе значення належить мові. Саме у взаємодії індивід прояснює власну ідентичність, намагаючись відповідати нормативним очікуванням партнера. У той же час він прагне виразу власної неповторності» [4].

На думку А.Ватерман ідентичність пов'язана 3 наявністю в індивіда чіткого самовизначення: вибір цілей, цінностей та переконань, що є елементами ідентичності. Науковець виокремлює найбільш значущі для формування ідентичності сфери: вибір професії та професійного шляху, прийняття та переоцінка релігійних та моральних переконань, прийняття низки соціальних ролей. Крім того, він підкреслює наявність двох сторін ідентичності: процесуальної - 3 набором засобів для відбору цінностей, цілей, переконань, а також змістовної - ціннісні спрямування як елемент ідентичності. [8]. Також варта уваги теорія соціальної ідентичності Г.Теджфела, де розглядаються особливості співвідношення особистісної та соціальної ідентичності у структурі Я-концепції особистості. Згідно з теорією в індивіда залежно від ситуації актуалізується або особистісна або соціальна ідентичність. В основі механізму запуску тієї чи іншої ідентичності лежить мотиваційна орієнтація особистості на досягнення позитивної самооцінки: використання міжгрупових форм поведінки (актуалізація соціальної ідентичності) чи опір на міжособистісне спілкування (актуалізація особистісної ідентичності) [8].

Б.Войчишке (Wojciszke) та М.Яримович (Jarymowicz) розглядають ідентичність як власну особистість пов'язану із процесом самосприйняття та внутрішньою перспективою індивіда. Також у психології виділяють терміни «індивідуальна ідентичність», яка складається із властивостей тіла, розуму, зовнішнього вигляду, генетичного коду, особистості, переконань та цінностей. Інший термін - «колективна ідентичність» визначає відчуття спільності та ідентифікації з іншими членами групи, що виражаєтся у понятті МИ [1]. Особистісна ідентичість це усвідомлення своєї неповторності/унікальності, відмінності від інших людей. Це самовизначення у фізичних термінах, інтелектуальних та моральних якостей особистості. Це свого роду набір ознак, які людина використовує, описуючи себе. Соціальна ідентичність - це оцінка значимості свого існування з точки зору суспільства, усвідомлення себе як елементу соціального світу. Вперше дане поняття було використано Х. Тайфелем, яке він визначав як належність індивіда до різних соціальних груп. Воно використовувалося для пояснення формування місця, яке особистість займає у суспільстві, яке сприймається як постійний результат процесу соціальної категорізації [1].

В нашій роботі ми використовуємо такі категорії як ідентичність, особистісна та соціальна ідентичність, та дотримуємося визначень, які були надані Б.Войчишке (Wojciszke) та М.Яримович (Jarymowicz).

Метою нашого дослідження було вивчення статево-вікових особливостей соціальної та особистісної ідентичності українців та поляків. Відповідно до мети дослідження були поставлені такі завдання:
1.Адаптація першої частини Демографічного опитувальника (В. Pietrulewicz,. J. Tivendell) до української вибірки.

2.Крос-культурне дослідження особливостей особистісної та соціальної ідентичності представників польської та української етнічних груп.

3.Порівняльна характеристика структурних компонентів ідентичності (за В. Pietrulewicz,. J. Tivendell): етнічні, статеві та вікові аспекти.

Виклад основного матеріалу дослідження. Вибірку склали 394 особи (203 українця та 191 поляк віком від 14 до 45 років). Досліджувані - представники різних навчальних закладів міста Житомира (Житомирський державний університет імені Івана Франка, Житомирський національний агроекологічний університет - Україна) та міста Варшави (WSM Вища школа менеджерська Польща). Опитування проводилося протягом 2015-2017 років.

Методи дослідження. Для розв'язання поставлених завдань використовувався комплекс методів: теоретичні (аналіз, порівняння, узагальнення, систематизація), методи статистичної обробки даних (обчислення середніх показників по двом вибіркам (середнє арифметичне), порівняння незалежних вибірок (t-критерій Стьюдента,). Автоматизована обробка даних здійснювалася за допомогою пакету програм STATISTICA 6.0.

Психодіагностична методика: Демографічний опитувальник (B.Pietrulewicz,. J. Tivendell). Даний метод був розроблений професором J. Tivendell 3 університету Монктон в Канаді. Методика складається 3 питань, що стосуються демографічних даних (вік, стать, регіональна приналежність) та трьох частин. Перша містить 18 питань, що стосуються індивідуальної та соціальної ідентичності (базується на аспектах анкети про ідентичність AIQ-III Cheek, Chan, Underwood (1994). Друга частина опитувальника містить 26 біполярних прикметників, які описують свою або інші етнічні групи (етнічні стереотипи). А також подається коротка інформація про країну (Канада). Остання, третя частина опитувальника, спрямована на вивчення етнічних інтересів соціального середовища досліджуваних, а також виявлення впливу цього середовища на прийняття рішень респондентами. Модифікований варіант дослідницького інструменту був використаний для дослідження в Польщі. Оригінальна версія анкети була модифікована та адаптована професором Університету імені Казимира Великого в м. Бидгощ Bogdan Pietrulewicz за згодою автора канадської версії. Друга частина інструменту збагачена 26 біполярними прикметниками, що описують польське населення, та короткі відомості про цю країну та їі мешканців [1] В Україні опитувальник модифікований Л. Журавльовою та О. Шмиглюк за згодою авторів опитувальника (B. Pietrulewicz,. J. Tivendell) та проходить адаптацію до українських реалій. Українська версія доповнена інформацією ще про три країни: Україна, Росія, Румунія.

Поданий опитувальник має наступні шкали: особистісна ідентичність; соціальна ідентичність; аутостереотипи (стереотипи щодо своєї етнічної групи); гетеростереотипи (стереотипи щодо інших етнічних груп); етнічні інтереси мікросоціуму досліджуваних; міра референтності цього мікросоціуму. Виходячи із мети дослідження, було використано та проаналізовано першу частину опитувальника, яка дозволяє вивчити особливості особистісної та 
соціальної ідентичності поляків та українців. Вивчення соціальної та особистісної ідентичності досліджуваних проводилося в 5 етапів.

Перший етап - дослідження особливостей ідентичності української етнічної групи (Таблиця 1.). Було створено ієрархію конструктів соціальної та особистої ідентичності. Виявлено, що найбільше значення для досліджуваних має самооцінка («Моя особиста оцінка себе $є$ важливою частиною того, ким я є»), що може свідчити про наявний переважаючий внутрішній локус контроль та тенденцію до саморозвитку та самовдосконалення. Також немалозначним є цілеспрямованість та рівень домагань («Мої цілі та амбіції на майбутнє - важлива частина того, ким я є»), це може говорити про те, що українці спрямовані на формування власного майбутнього, відчувають відповідальність за нього та необхідність змін. Наступні сходинки в ієрархії займають такі категорії: вірність собі, цінності, морально-етичні переконання («Бути вірним собі(принципам, переконанням, ідеям тощо), незалежно від життєвих обставин, є дуже важливим для мене» та «Мої цінності і моральні переконання - важлива частина того, ким я є») - високі показники по даним твердженням можуть говорити про цілісність та внутрішню стабільність особистості досліджуваних, слідуванню виробленій та перевіреній стратегії поведінці, яка не залежить від зовнішніх впливів. Як бачимо, із таблиці 1. для української вибірки важливими також є когніції та емоції («Мої думки та ідеї - важлива складова того, ким я є», «Мої почуття та емоції є важливою частиною того, ким я є»), що свідчить про гармонійне сприйняття себе на когнітивному та емоційному рівнях. Важливість та насиченість внутрішнього світу досліджуваних, що впливає на усвідомлення себе та формування Я-образу, підтверджуються високими оцінками, які респонденти надали твердженню «Мій образ самого себе і те, що я знаю про себе - важлива частина того, ким я є».

Також бачимо необхідність досліджуваних у схвалені з боку оточуючих та важливості їх реакції та думки, що знаходить своє підтвердження у високих показниках по такому твердженню як: «Моя поведінка в соціумі, така ж як і мій спосіб реагування, коли зустрічаю когось - важлива частина того, ким я є».

Другий етап передбачав дослідження соціальної та особистісної ідентичності польської етнічної групи (Таблиця 1.). Було створено ієрархію конструктів ідентичності поляків. Виявлено, що найбільше значення для досліджуваних мають цінності та морально-етичні переконання («Мої цінності і моральні переконання - важлива частина того, ким я є»), що може свідчити про постконвенційний рівень розвитку моралі, високий розвиток ціннісної та морально-етичної сфери досліджуваних як наслідок соціально-культурних особливостей виховання. Також поляки надають важливе значення емоціям («Мої почуття та емоції $є$ важливою частиною того, ким я є»), що може говорити про розвиток афективної сфери, темпераментні етнічні особливості а також свідчить про необхідність для досліджуваних переживати та висловлювати свої емоції.

Таблиця 1. Загальні показники особистісної та соціальної ідентичності української та польської вибірки

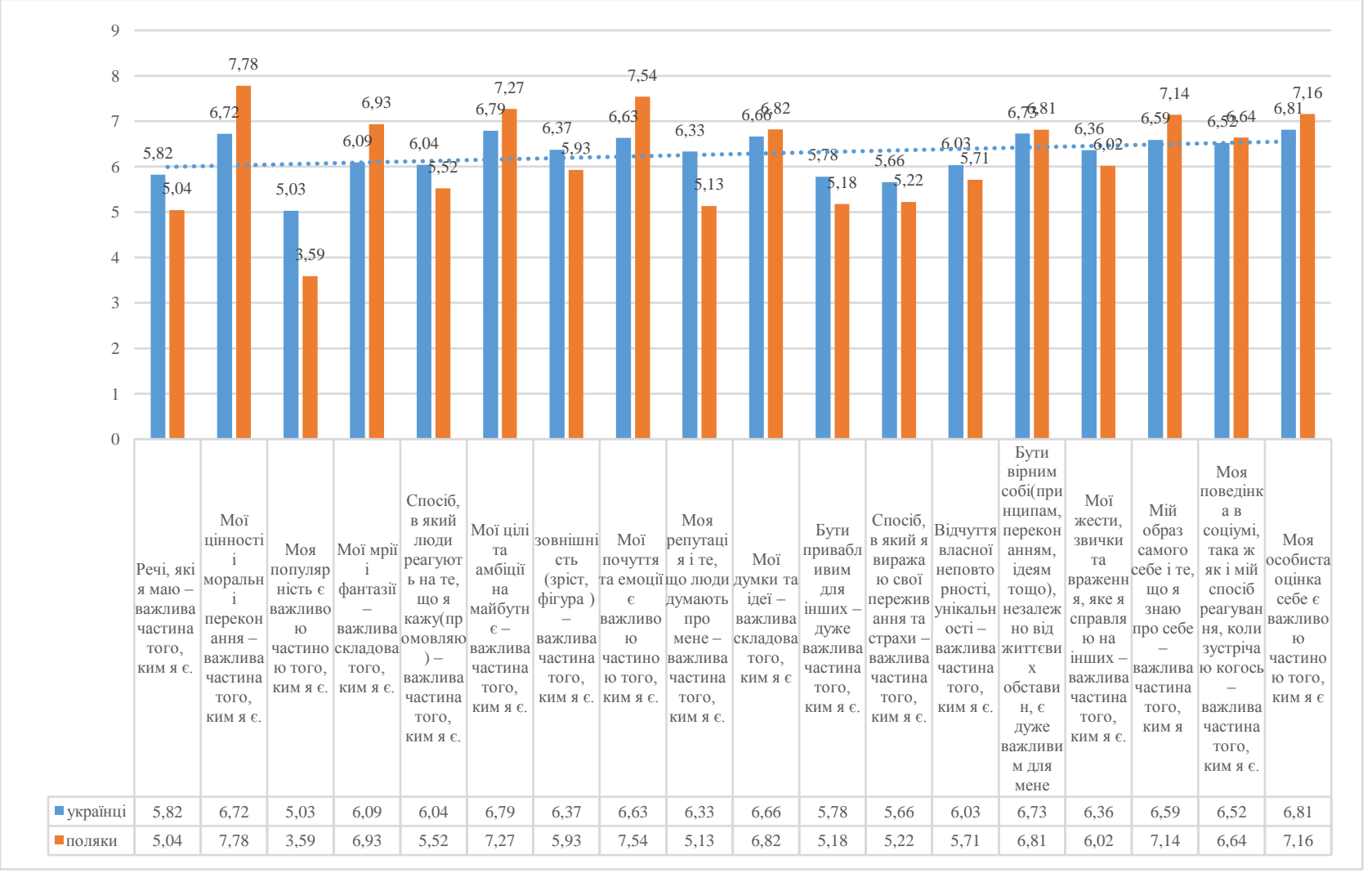

Важливе місце в ієрархії конструктів для польської групи досліджуваних є цілеспрямованість та рівень домагань («Мої цілі та амбіції на майбутнє - важлива частина того, ким я є»), що описує досліджуваних як таких, що спрямовані на формування власного майбутнього, відчувають відповідальність за нього та необхідність змін.

Наступними категоріями по значимості є самооцінка («Моя особиста оцінка себе є важливою частиною того, ким я є»), образ себе («Мій образ самого себе і те, що я 
знаю про себе - важлива частина того, ким я є»), когніції («Мої думки та ідеї - важлива складова того, ким я є»), вірність собі («Бути вірним собі(принципам, переконанням, ідеям тощо), незалежно від життєвих обставин, є дуже важливим для мене»). Поведінка та схвалення 3 боку оточуючих («Моя поведінка в соціумі, така ж як і мій спосіб реагування, коли зустрічаю когось - важлива частина того, ким я є»). Варто зазначити, що на відмінну від українських респондентів, представники польської етнічної групи важливе значення надають своїм мріям i фантазіям.

На третьому етапі дослідження було зроблено порівняльний аналіз та виявлено статистичну значимість отриманих відмінностей між польською та українською вибірками (Таблиця 2.). Для перевірки статистичної значимості відмінностей у структурі особистісної та соціальної ідентичності польської та української етнічностей було застосовано t-критерій Стьюдента. Виявлено, що такі конструкти соціальної ідентичності як: речі, популярність, реакція інших, зовнішність, репутація, привабливість для інших, та особистісної ідентичності: цінності та моральні переконання, мрії та фантазії, цілі та рівень домагань, почуття та емоції, вираження переживань та страхів, образ себе мають статистично значимі відмінності між двома вибірками. Доведено переважання особистісної ідентичності в українській та польській етнічних групах. Констатовано важливість самооцінки, як категорії ідентичності, для українців та цінностей, моральних переконань - для поляків. Найнижчі показники в ієрархічній структурі ідентичності для обох етнічних груп отримала категорія популярність.

Четвертий етап дослідження передбачав порівняльний аналіз статевих відмінностей між двома етнічними групами. Було створено ієрархію конструктів ідентичності поляків-чоловіків, українців-чоловіків, польок та українок. Виявлено, що найбільше значення для досліджуваних чоловіків -поляків мають цінності та моральноетичні переконання, Я-образ, цілі та рівень домагань, когніції, мрії та фантазії, самооцінка, вірність собі, поведінка. Для українців на першому місці знаходяться цілі та рівень домагань, потім ідуть такі конструкти ідентичності як вірність собі, когніції, цінності та моральні переконання, Я-образ, почуття та емоції, репутація, зовнішність. Для перевірки статистичної значимості відмінностей у структурі особистісної та соціальної ідентичності польської та української етнічностей було застосовано t-критерій Стьюдента. Виявлено, що такі конструкти соціальної ідентичності як: речі, популярність, реакція інших, зовнішність, репутація та особистісної ідентичності: цінності та моральні переконання, мрії та фантазії, вираження переживань та страхів мають статистично значимі відмінності між двома вибірками. Доведено переважання особистісної ідентичності в українській та польській етнічних групах. Констатовано важливість цілей та рівня домагань, як категорії ідентичності, для українців та цінностей, моральних переконань - для поляків. Найнижчі показники в ієрархічній структурі ідентичності для обох етнічних груп отримала категорія популярність.

Таблиця 2. Загальні показники особистісної та соціальної ідентичності української та польської вибірки: статеві особливості

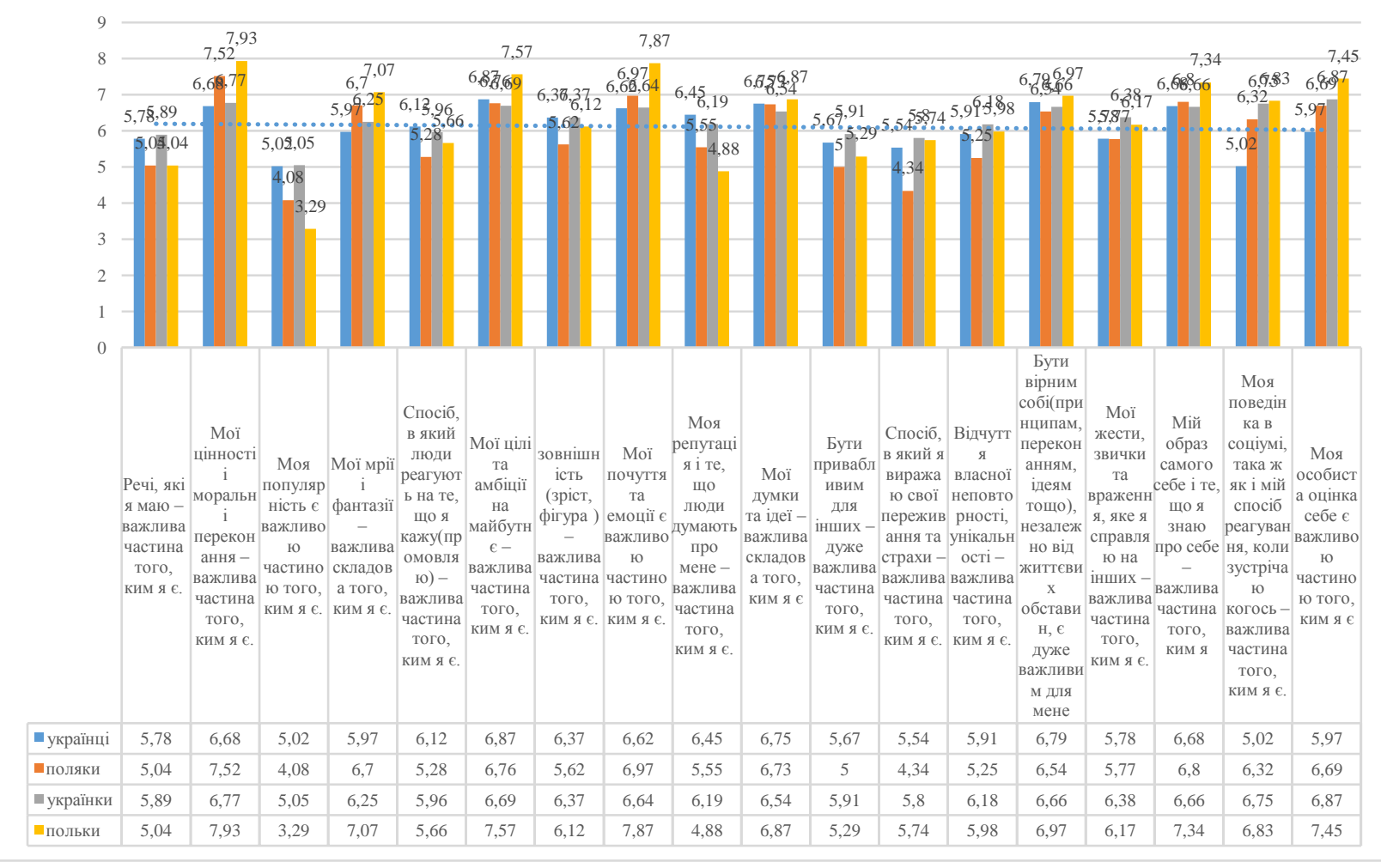

Відмінність між чоловічою та жіночою вибірками полягає у тому, що для жінок (як польок так і українок) на відміну від чоловіків важливим є поведінка («Моя поведінка в соціумі, така ж як і мій спосіб реагування, коли зустрічаю когось - важлива частина того, ким я є»), що може свідчити про переважання цінності у міжособистісній комунікації жінок, а також про переважаючий внутрішній локус контроль та тенденцію до саморозвитку та самовдосконалення, підтвердженням чого слугують високі показники по твердженню: «Моя особиста оцінка себе $\epsilon$ важливою частиною того, ким я є». 
Іерархія структурних компонентів ідентичності польок виглядає таким чином: цінності та моральні переконання, Я-образ, цілі та рівень домагань, мрії та фантазії, вірність собі, когніції, поведінка. Для українок найважливішим є самооцінка, потім ідуть такі конструкти ідентичності як: цінності та моральні переконання, поведінка, цілі та рівень домагань, вірність собі, Я-образ, почуття та емоції, когніції, зовнішність, враження інших, мрії та фантазії. Для перевірки статистичної значимості відмінностей у структурі особистісної та соціальної ідентичності польської та української етнічностей було застосовано tкритерій Стьюдента. Виявлено, що такі конструкти соціальної ідентичності як: речі, популярність, репутація, привабливість для інших та особистісної ідентичності: цінності та моральні переконання, мрії та фантазії, цілі та рівень домагань, почуття та емоції, Я-образ мають статистично значимі відмінності між двома вибірками. Доведено переважання особистісної ідентичності в українській та польській етнічних групах. Констатовано важливість самооцінки, як категорії ідентичності, для українок та цінностей, моральних переконань - для польок. Найнижчі показники в ієрархічній структурі ідентичності для обох етнічних груп отримала категорія популярність.

П'ятий етап дослідження передбачав порівняльний аналіз вікових особливостей ідентичності поляків та українців (Таблиця 3.). Було створено ієрархію конструктів ідентичності поляків-підлітків, поляків-юнаків, поляківмолоді, українців-підлітків, юнаків, молоді. Виявлено, що найбільше значення для досліджуваних підлітків - поляків мають цінності та морально-етичні переконання, мрії та фантазії, цілі та рівень домагань, почуття та емоції, когніції, Я-образ, поведінка, самооцінка. Ієрархічна структура українців-підлітків виглядає так: Я-образ, поведінка, привабливість для інших, цілі та рівень домагань, цінності та моральні переконання, зовнішність, враження інших, самооцінка. Для перевірки статистичної значимості відмінностей у структурі ідентичності польської та української вибірок було застосовано t-критерій Стьюдента. Виявлено, що такі конструкти соціальної ідентичності як: популярність, реакція інших, зовнішність, репутація, привабливість для інших,, враження інших, поведінка та особистісної ідентичності: вираження переживань та страхів мають статистично значимі відмінності між двома вибірками. Доведено переважання особистісної ідентичності в українській та польській етнічних групах. Констатовано важливість Я-образу, як категорії ідентичності, для українців та цінностей, моральних переконань - для поляків. Найнижчі показники в ієрархічній структурі ідентичності для обох етнічних груп отримала категорія популярність.

Таблиця 3. Загальні показники особистісної та соціальної ідентичності української та польської вибірки: вікові особливості

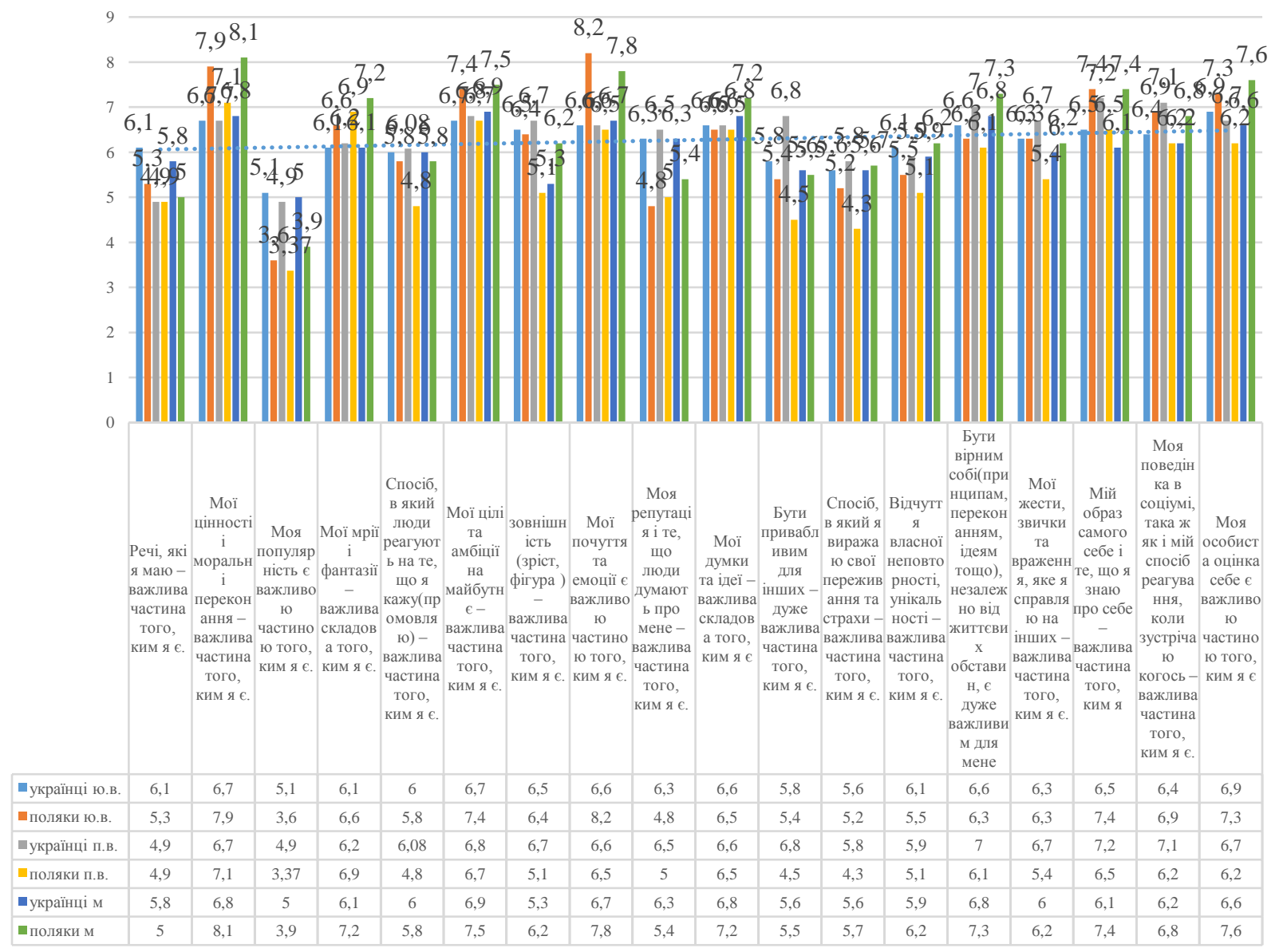

Для досліджуваних юнаків, представників польської етнічної групи, на першому місці у структурі ідентичності посідають почуття та емоції, наступними конструктами по значимості є цінності та моральні переконання, цілі та рівень домагань, Я-образ, самооцінка, цілі та амбіції, вірність собі когніції. Ієрархія конструктів ідентичності українців юнацького віку має таку структуру: самооцінка, цілі та рівень домагань, цінності та моральні пере- 
конання, почуття та емоції, когніції, вірність собі, Я-образ. 3 метою перевірки статистичної значимості відмінностей у структурі ідентичності польської та української вибірок було застосовано t-критерій Стьюдента. Виявлено, що такі конструкти соціальної ідентичності як: речі, популярність, репутація, поведінка та особистісної ідентичності: цінності та моральні переконання, цілі та рівень домагань, почуття та емоції, Я-образ мають статистично значимі відмінності між двома вибірками. Доведено переважання особистісної ідентичності в українській та польській етнічних групах. Констатовано важливість самооцінки, як категорії ідентичності, для українців та почуття та емоції - для поляків. Найнижчі показники в ієрархічній структурі ідентичності для обох етнічних груп отримала категорія популярність. Польська молодь в ієрархічній структурі ідентичності має цінності та моральні переконання, почуття та емоції, самооцінку, цілі та рівень домагань, Я-образ, вірність собі, когніції, мрії та фантазії. Для української вибірки, найважливіше значення мають цілі та рівень домагань, цінності та моральні переконання, когніції, вірність собі, почуття та емоції, самооцінка. Для перевірки статистичної значимості відмінностей у структурі ідентичності польської та української вибірок було застосовано t-критерій Стьюдента. Виявлено, що такі конструкти соціальної ідентичності як: зовнішність та особистісної ідентичності: цінності та моральні переконання, мрії та фантазії, почуття та емоції, Я-образ, самооцінка мають статистично значимі відмінності між двома вибірками. Доведено переважання особистісної ідентичності в українській та польській етнічних групах. Констатовано важливість цілей та рівня домагань, як категорії ідентичності, для українців та цінностей, моральних переконань - для поляків. Найнижчі показники в ієрархічній структурі ідентичності для обох етнічних груп отримала категорія популярність.

Дані, які представлені у таблиці 3, говорять про те, що як для підлітків так і для юнаків, представників польської та української етнічних груп важливими є твердження «Мої цінності і моральні переконання - важлива частина того, ким я є», але більш високі бали поставили полякиюнаки. Також важливим для усіх досліджуваних є цілі та амбіції на майбутнє, але у поляків юнацького віку показ- ники є дещо вищими. Усі респонденти схильні до надання значенню тим почуттям та емоціям, що переживаються ними. Досліджувані також високо оцінили такі твердження як «Мій образ самого себе і те, що я знаю про себе - важлива частина того, ким я є» та «Моя особиста оцінка себе $\epsilon$ важливою частиною того, ким я є». як і попередньо, найвищі бали були надані поляками-юнаками. «Бути вірним собі(принципам, переконанням, ідеям тощо), незалежно від життєвих обставин, є дуже важливим для мене», це твердження отримало високі показники від усіх досліджуваних, окрім поляків-підлітків(середній рівень). Також варто зазначити, що для підлітків українців значимими характеристиками є зовнішність та жести, звички, враження, яке вони справляють на інших, репутація та думка інших. Власне такі показники є закономірними і цілком відповідають віковим особливостям даного періоду.

\section{Висновки.}

1. На основі здійсненого теоретичного аналізу ми можемо говорити про те, що формування ідентичності - це динамічний процес, який відбувається протягом усього життя людини. А ідентичність - це той фундамент/основа, який визначає світогляд людини, впливає на формування картини світу та Я-образу особистості, усвідомлення та розуміння себе та оточуючих, що визначає здорову, гармонійну поведінку особистості в суспільстві.

2. Існують етнічні, статеві та вікові відмінності в ієрархічній структурі ідентичності представників різних етнічних груп.

3.Представники польської етнічної групи, незалежно від вікових та статевих особливостей пріоритетне значення надають цінностям та моральним переконанням, що дає підстави стверджувати про переважання постконвенційної моралі як культурної особливості.

4. Для української етнічної групи переважаючим конструктом ідентичності виступає самооцінка, що може свідчити про наявний переважаючий внутрішній локус контроль та тенденцію до саморозвитку й самовдосконалення як етнічної особливості українців.

Виявлення психологічних чинників, які зумовлюють дані відмінності $є$ перспективою подальших наукових розвідок

\section{ЛIТЕРАТУРА}

1. Leszcz J., Magierek K.,. Pietrulewicz B, Tivendell J. ME-YOU, WE-THEY - a couple of words about national stereotypes on the example of Polish and Canadian respondents. Journal : Polish Journal of Social Science, 2014, Volume: IX, Issue: 1, Pages: 105136.

2. Антонова Н.В. Проблема личностной идентичности в интерпретации современного психоанализа, интеракционизма и когнитивной психологии. Вопросы психологии. 1996, №1, с. 129-134.

3. Гальченко О. Понятие идентификации в теории 3. Фрейда. Развитие личности, 2011, №2, с. 106-115 URL https://cyberleninka.ru/article/n/ponyatie-identifikatsii-v-teorii-zfreyda

4. Гнатенко П.І. Ідентичність: філософський та психологічний аналіз. Київ.:АРТ-ПРЕС, 1999, 466 с.

5. Иванова Н.Л. Социальная идентичность: теория и практика. Москва : СГУ, 2009. - 453 с.

6. Кондратьев М.Ю. Азбука социального психолога -практика.

7. Правдивець Н. О. Теоретична модель феномену ідентичності особистості. Актуальні проблеми психології : Організаційна психологія. Економічна психологія. Соціальна психологія : зб. наук. праць / за ред. С. Д. Максименка, Л. М. Карамушки. К.иїв: Видавництвово «А.С.К.», 2010, Т. 1, Ч. 27, с. 137-145.

8. Тищенко Л. В. Самоідентичність особистості як загальнопсихологічна проблема. Науковий вісник Миколаївського державного університету імені В. О. Сухомлинського. Психологічні науки, 2013, Т. 2, №10, с. 299-303. URL : http://nbuv.gov.ua/UJRN/Nvmdups_2013_2_10_59.

9. Шнейдер Л.Б. Профессиональная идентичность: Монография. Москва: МОСУ, 2001, 233 с.

10. Эриксон Э. Идентичность: юность и кризис. Москва: Флинта: МПСИ: Прогресс, 2006, 352 с.

11. Эриксон Э. Проблемы Эго-идентичности. Реферантивный журнал. Социология, 1991, №1, с. 173-200. 


\section{REFERENCES}

2. Antonova N.V. The problem of the personality identity in the interpretation of modern psychoanalysis, interactiosm and cognitive psychology. Questions of psychology. 1996, №1, p. 129-134.

3. Galchenko $\mathrm{O}$. The concept of the identification in the theory of $\mathrm{Z}$ Freud. Development of the person, 2011, №2, p. 106 - 115 URL https://cyberleninka.ru/article/n/ponyatie-identifikatsii-v-teorii-zfreyda

4. Hnatenko P.I. Identity: philosophical and psychological analysis. Kiev.: APT-PRESS, 1999, 466 p.

5. Ivanova N.L. Social Identity: Theory and Practice. Moscow: SSU, 2009, 453 p.

6. Kondratyev M.Yu. ABC Social Psychologist -Practice. Moscow: PERSE, 2007, $464 \mathrm{p}$

7. Pravdyvets N.O. Theoretical model of the phenomenon of identity of the personality. Actual issues of psychology: Organizational psychology. Economic psychology. Social Psychology: Sciences Works / ed. S. D. Maksimenko, L. M. Karamushki. Kyiv: Publishing House "ASK", 2010, T. 1, Ch. 27, p. 137-145.

8. Tishchenko L.V. Identity of the individual as a general psychological problem. Scientific Herald of V.O. Sukhomlynskyy Mykolaiv State University. Psychological Sciences, 2013, T. 2, No. 10, p. 299-303. URL: http://nbuv.gov.ua/UJRN/Nvmdups_2013_2_10_59.

9. Schneider L. B. Professional Identity: Monograph. Moscow: MOSU, 2001, 233 p.

10. Erickson E. Identity: youth and crisis. Moscow: Flint: MPSI: Progress, 2006, $352 \mathrm{p}$.

11. Erickson E. Problems of Ego-Identity. Reflective magazine. Sociology, 1991, No. 1, p. 173-200

\section{Identity age and gender peculiarities: cross-cultural aspect}

\section{O. H. Shmyglyuk}

Abstract. The article is devoted to the study of the personality and social identity of Polish and Ukrainian ethnic groups representatives. According to the theoretical analysis, identity is the foundation/basis that determines the person's worldview, affects the formation of this worldview and the self-image of the personality, understanding of oneself and others, which determines the healthy, harmonious personality behavior in society. It is found that there are ethnic and gender-centric differences in the hierarchical structure of the identity. It is stated that the predominance of the construct of values and moral convictions are observed in modern poles, and the self-esteem for the Ukrainian sample is the most important.

Keywords: identity, personality identity, socia identity, the Ukrainians, the Poles, ethnos ethnic self-consciousness. 